\title{
PERLINDUNGAN DAN PELESTARIAN BENDEGA SEBAGAI ORGANISASI TRADISIONAL NELAYAN DI BALI
}

\author{
Oleh: \\ I Putu Sastra Wibawa
}

sastra@unhi.ac.id

Fakultas Hukum Universitas Hindu Indonesia

Proses Review 5-20 April, Dinyatakan Lolos 23 April

\begin{abstract}
The protection and preservation of bendega (fishermen) as traditional fishing organization has been regulated in the Bali Provincial Regulation Number 11 of 2017 concerning Bendega. Then based on the provision of article 4 the regulation has been spelled out in Denpasar Regency Regulation Number 6 of 2019 concerning Protection and Preservation of Bendega and Badung District Regulation Number 6 of 2019 concerning Protection and Preservation of Bendega as a follow-up rule. The Bali Provincial Regulation Number 11 of 2017 concerning Bendega contains the principle of legal pluralism. There are several elements that describe a triangle. First, the upper corner contains elements of ethical values, morals, and religious teachings (in this case the Bendega Law is represented by the Tri Hita Karana teachings and Hindu religious teachings as the basis for the protection and preservation of the fishermen in Bali). Second, the left corner of the triangle contains elements of state law (in this case the Bendega Regional Regulation is represented by elements of the Regional Government and the Governor as part of the state legal structure, while the legal substance is represented by the Bali Provincial Regulation on Bendega and continued its regulation in the Regulations of the Regency/City governing Bendega Protection and Preservation). Third, the right corner of the triangle contains elements of customary law or elements of indigenous peoples (in this case in the Bendega Regional Regulation represented by the elements of the Krama Bendega, Prajuru Bendega, and awig-awig Bendesa organizations). The regulation may be classified in strong legal pluralism.
\end{abstract}

Keywords: Protection, Preservation, Bendega, Legal Pluralism

\begin{abstract}
Abstrak
Pengaturan tentang perlindungan dan pelestarian bendega sebagai organisasi tradisional nelayan telah di atur dalam Peraturan Daerah Provinsi Bali Nomor 11 Tahun 2017 tentang Bendega. Kemudian berdasarkan ketentuan pasal 4 peraturan tersebut telah dijabarkan dalam Peraturan Daerah Kabupaten Denpasar Nomor 6 Tahun 2019 tentang Perlindungan dan Pelestarian Bendega dan Peraturan Daerah Kabupaten Badung Nomor 6 Tahun 2019 tentang Perlindungan dan
\end{abstract}


Pelestarian Bendega sebagai aturan tindak lanjutnya. Peraturan Daerah Provinsi Bali Nomor 11 Tahun 2017 tentang Bendega mengandung prinsip pluralisme hukum. Terdapat beberapa unsur yang menggambarkan sebuah segitiga. Pertama, sudut bagian atas mengandung unsur nilai etika, moral dan ajaran agama (dalam hal ini dalam Perda Bendega di wakili unsur ajaran tri hita karana dan ajaran agama Hindu sebagai landasan perlindungan dan pelestarian bendega di Bali). Kedua, sudut segitiga bagian kiri mengandung unsur hukum negara (dalam hal ini dalam Perda Bendega di wakili unsur Pemerintah Daerah dan Gubernur sebagai bagian struktur hukum negara, sedangkan substansi hukum diwakili oleh Peraturan Daerah Provinsi Bali tentang Bendega dan dilanjutkan pengaturannya dalam Peraturan Daerah Kabupaten/ Kota yang mengatur tentang Perlindungan dan Pelestarian Bendega). Ketiga, sudut segitiga bagian kanan mengandung unsur hukum adat atau unsur masyarakat adat (dalam hal ini dalam Perda Bendega di wakili unsur krama bendega, prajuru bendega, dan awig-awig organisasi bendesa). Tergolong dalam pluralisme hukum kuat.

Kata Kunci: Perlindungan, Pelestarian, Bendega, Pluralisme Hukum

\section{PENDAHULUAN}

Negara Indonesia adalah negara hukum modern. Maksudnya selain aspek kepastian hukum dimana semua kegiatan bernegara harus didasari aturan hukum terdapat tujuan lainnya yang ingin di capai yakni sebagai negara kesejahteraan (welfare state). Penjabaran konsep negara kesejahteraan selayaknya sampai menyentuh ke masyarakat pinggiran, salah satunya mayarakat yang memiliki mata pencaharian sebagai nelayan.

Provinsi Bali merupakan sebuah pulau kecil yang memiliki garis pantai yang cukup Panjang. Sehingga dengan keberadaan pantai yang ada terdapat masyarakat Bali yang memiliki mata pencaharian sebagai nelayan. Nelayan di Bali memiliki organisasi tradisional yang bernama Bendega.Secara umum bendega yang merupakan lembaga tradisonal dibidang kelautan dan perikanan yang berada di wilayah pesisir yang memiliki karakteristik sosial relegius yang secara historis terus tumbuh dan berkembang sesuai dengan budaya dan kearifan lokal Bali. Keberadaan Bendega di Bali selama ini telah memberikan kontribusi dalam bentuk pembangunan dalam lingkup palemahan, pawongan dan parhyangan.

Bendega berfungsi membangun dan mengelola wilayah pesisir yang diarahkan untuk peningkatan sebesar-besarnya bagi kesejahteraan masyarakat. Bentuk pengelolaan wilayah pesisir yang berkaitan dengan kegiatan keagamaan, ekonomi dan sosial tentu tidak dapat terlepas dari keberadaan masyarakat pesisir. Perlindungan dan Pelestarian Bendega sebagai lembaga tradisional yang bergerak dibidang perekonomian, sosial, kebudayaan dan relegius yang berlandasakan pada tri hita karana tersebut sangat diperlukan. Bendega yang merupakan bagian dari budaya tradisional Bali berperan dan berfungsi untuk meningkatkan kesejahteraan kirama bendega, dengan demikian bendega perlu diakui dan dihormati keberadaan beserta hak-hak tradisionalnya. Pengakuan dan perlindungan termasuk perlindungan dan pelestarian Bendega harus berdasarkan pada falsafah tri hita karana dan bersumber pada ajaran agama Hindu di Bali. Berdasarkan uraian tersebut maka penting untuk dikemukan bentuk perlindungan dan pelestarian bendega di Bali termasuk model pengaturannya.

\section{PEMBAHASAN}

\subsection{Perlindungan dan Pelestarian Bendega Merupakan Politik Hukum Negara Bersumber dari Nilai yang Berlaku di Masyarakat}

Pengakuan negara terhadap organisasi tradisional yang ada khususnya di Bali salah satunya bendega sangat diperlukan untuk mendapatkan perlindungan dan pelestarian. Hal ini diperlukan dalam rangka pelestarian kearifan lokal dan budaya tradisional Bali sebagaimana diamanatkan oleh Pancasila dan Undang-Undang Dasar Negara Republik Indonesia Tahun 1945. 
Politik hukum negara yang mengarah pada penghormatan terhadap bendega tentunya tidak dapat lepas dari prinsip-prinsip berbangsa dan bernegara. Sesuai dengan nilai-nilai Pancasila, Undang-Undang Dasar Negara Republik Indonesia Tahun 1945, Bhineka Tunggal Ika dan Negara Kesatuan Republik Indonesia. Politik hukum menurut Padmo Wahjono (1986: 160), sebagai kebijakan dasar yang menentukan arah, bentuk, dan isi hukum yang dibentuk. Definisi ini masih bersifat abstrak. Kemudian dinyatakan bahwa politik hukum adalah kebijakan penyelenggara negara tentang apa yang dijadikan kriteria untuk menghukumkan sesuatu. Dalam hal ini kebijakan tersebut dapat berkaitan dengan pembentukan hukum, penerapan hukum, dan penegakannya sendiri (Padmo Wahyono, 1991: 65).

Selanjutnya, menurut Soedarto (1983: 20), politik hukum adalah kebijakan negara melalui badan-badan negara yang berwenang untuk menetapkan peratura-peraturan yang dikehendaki, yang diperkirakan digunakan untuk nengekspresikan apa yang terkandung dalam masyarakat dan untuk mencapai apa yang dicita-citakan. Sunaryati Hartono (1991: 1) menyatakan politik hukum sebagai sebuah alat (tool) atau sarana dan langkah yang dapat digunakan oleh pemerintah untuk menciptakan sistem hukum nasional yang dikehendaki. Dengan sistem hukum nasional itu diwujudkan cita-cita bangsa Indonesia. Satjipto Rahardjo (2000: 35), mendefinisikan politik hukum sebagai aktivitas memilih dan cara yang hendak dipakai untuk mencapai suatu tujuan sosial dan hukum tertentu dalam masyarakat. Selanjutnya, dalam Abdul Hakim Garuda Nusantara (Mahfud, MD, 2010: 15), politik hukum adalah kebijakan hukum (legal policy) yang hendak diterapkan atau dilaksanakan oleh suatu pemerintahan negara tertentu.

Berdasarkan pendapat ahli di atas, digunakan teori politik hukum menurut Padmo Wahyono, yaitu bahwa politik hukum adalah kebijakan dasar penyelenggara negara dalam bidang hukum yang sedang dan telah berlaku, yang bersumber dari nilai-nilai yang berlaku di masyarakat untuk mencapai tujuan negara yang dicita-citakan. Kata kebijakan di atas berkaitan dengan adanya strategi yang sistematis, terperinci, dan mendasar. Dalam merumuskan dan menetapkan hukum yang telah dan dilakukan, politik hukum menyerahkan otoritas legislasi kepada penyelenggara negara, tetapi dengan tetap memperhatikan nilai-nilai yang berlaku di masyarakat, semuanya diarahkan dalam rangka mencapai tujuan negara yang dicita-citakan (Frans Magnis Suseno, 1994: 310314).

Berkaitan dengan perlindungan dan pelestarian bendega diperlukan politik hukum pemerintah untuk membentuk hukum yang bersumber dari nilai-nilai yang berlaku di masyarakat, khususnya masyarakat Bali yang bergabung dalam organisasi bendega sehingga tujuan negara tercapai yakni negara yang sejahtera, adil dan makmur. Menarik juga untuk merujuk pendapat dari William Zevenbergen (2011: 19) yang mengutarakan bahwa politik hukum mencoba menjawab pertanyaan, peraturan-peraturan hukum mana yang patut untuk dijadikan hukum. Perundang-undangan itu sendiri merupakan bentuk politik hukum (legal policy). Pengertian legal policy, mencakup proses pembuatan dan pelaksanaan hukum yang dapat menunjukkan sifat dan ke arah mana hukum dibangun. Politik hukum memberikan landasan terhadap proses pembentukan hukum yang lebih sesuai dengan situasi dan kondisi, kultur serta nilai yang berkembang di masyarakat dengan memperhatikan kebutuhan masyarakat terhadap hukum itu sendiri.

Menurut pandangan di atas politik hukum dapat dibedakan menjadi dua dimensi. Pertama, politik hukum yang menjadi alasan dasar diadakannya suatu peraturan perundangundangan. Kedua, tujuan atau alasan yang muncul di balik pemberlakuan suatu peraturan perundang-undangan. Dalam pembuatan peraturan perundang-undangan, politik hukum memiliki peranan sangat penting. Pertama, sebagai alasan mengapa diperlukan pembentukan suatu peraturan perundangundangan. Kedua, untuk menentukan apa yang hendak diterjemahkan ke dalam kalimat hukum dan menjadi perumusan pasal. Dua hal ini penting karena keberadaan peraturan perundang-undangan dan perumusan pasal merupakan jembatan antara politik hukum tersebut dalam tahap implementasi peraturan 
perundang-undangan. Hal ini mengingat antara pelaksanaan peraturan perundang-undangan harus ada konsistensi dan korelasi yang erat dengan apa yang ditetapkan sebagai politik.

\subsection{Pengaturan Bendega Melalui Produk Hukum Daerah}

Bendega adalah lembaga tradisional dibidang kelautan dan perikanan pada masyarakat adat di Bali yang ada di wilayah pesisir, bersifat ekonomi, sosial, budaya dan religius yang secara historis terus tumbuh dan berkembang sesuai dengan budaya dan kearifan lokal Bali. Pengaturan tentang bendega telah di atur dalam Peraturan Daerah Provinsi Bali Nomor 11 Tahun 2017 tentang Bendega. Pengaturan bendega tersebut memiliki dasar filosofis, sosiologis dan yuridis. Secara filosofis, pengaturan bendega didasariatas pertimbangan, antara lain: 1) bahwa bendega sebagai lembaga tradisional yang bersifat sosial budaya dan relegius dibidang perikanan merupakan bagian dari budaya tradisional Bali, perlu diakui dan dihormati keberadaannya beserta hak-hak tradisionalnya dan 2) bahwa peran dan fungsi bendega yang berdasar pada falsafah tri hita karana dan bersumber pada ajaran agama Hindu di Bali sangat penting dan strategis terutama dalam pembangunan ekonomi, sosial dan budaya serta religius maka bendega perlu mendapat pengaturan yang jelas untuk kepastian hukum. Sedangkan secara sosiologis leberadaan bendega sebagai organisasi tardisional nelayan di Bali masih eksis baik secara kelembagaan maupun secara aktivitas sosial, ekonomi dan religius.

Sedangkan landasan yuridisnya dapat dilihat dari ketentuan mengingat dalam Peraturan Daerah Provinsi Bali Nomor 11 Tahun 2017 tentang Bendega, yang berkaitan dengan pengaturan bendega di Bali, antara lain:

1. Pasal 18 ayat (6) Undang-Undang Dasar Negara Republik Indonesia Tahun 1945;

2. Undang-Undang Nomor 64 Tahun 1958 tentang Pembentukan Daerah-daerah Tingkat I Bali, Nusa Tenggara Barat dan Nusa Tenggara Timur (Lembaran Negara Republik Indonesia Tahun 1958 Nomor 115, Tambahan Lembaran Negara Republik Indonesia Nomor 1649);
3. Undang-Undang Nomor 31 Tahun 2004 tentang Perikanan (Lembaran Negara Republik Indonesia Tahun 2004 Nomor 118, Tambahan Lembaran Negara Republik Indonesia Nomor 4433) sebagaimana telah diubah dengan UndangUndang Nomor 45 Tahun 2009 tentang Perubahan Atas Undang-Undang Nomor 31 Tahun 2004 tentang Perikanan (Lembaran Negara Republik Indonesia Tahun 2009 Nomor 154, Tambahan Lembaran Negara Republik Indonesia Nomor 5073);

4. Undang-Undang Nomor 23 Tahun 2014 tentang Pemerintahan Daerah (Lembaran Negara Republik Indonesia Tahun 2014 Nomor 244, Tambahan Lembaran Negara Republik Indonesia Nomor 5587) sebagaimana telah diubah beberapa kali terakhir dengan Undang-Undang Nomor 9 Tahun 2015 Tentang Perubahan Kedua Atas UndangUndang Nomor 23 Tahun 2014 Tentang Pemerintahan Daerah (Lembaran Negara Republik Indonesia Tahun 2015 Nomor 58, Tambahan Lembaran Negara Republik Indonesia Nomor 5679);

5. Undang-Undang Nomor 27 Tahun 2007 tentang Pengelolaan Wilayah Pesisir dan Pulau-Pulau Kecil (Lembaran Negara Republik Indonesia Tahun 2007 Nomor 84, Tambahan Lembaran Negara Republik Indonesia Nomor 4739), sebagaimana telah diubah dengan Undang-Undang Nomor 1 Tahun 2014 tentang Perubahan Atas Undang-Undang Nomor 27 Tahun 2007 Tentang Pengelolaan Wilayah Pesisir dan PulauPulau Kecil (Lembaran Negara Republik Indonesia Tahun 2014 Nomor 2, Tambahan Lembaran Negara Republik Indonesia Nomor 5490);

6. Undang-Undang Nomor 7 Tahun 2016 tentang Perlindungan dan Pemberdayaan Nelayan, Pembudi Daya Ikan, dan Petambak Garam (Lembaran Negara Republik Indonesia Tahun 2016 Nomor 68, Tambahan Lembaran Negara Republik Indonesia Nomor 5870);

7. Peraturan Pemerintah Nomor 50 Tahun 
2015 tentang Pemberdayaan Nelayan Kecil Dan Pembudidaya-Ikan Kecil (Lembaran Negara Republik Indonesia Tahun 2015 Nomor 166, Tambahan Lembaran Negara Republik Indonesia Nomor 5719).

Secara umum Peraturan Daerah Provinsi Bali Nomor 11 Tahun 2017 tentang Bendega terdiri dari IX Bab dan 19 Pasal ditetapkan pada tanggal 9 Oktober 2017 Lembaran Daerah Provinsi Bali Tahun 2017 Nomor 11, Noreg Peraturan Daerah Provinsi Bali: (11/232/2017), Tambahan Lembaran Daearah Provinsi Bali Nomor 9, adapun rincian singkatnya dapat dilihat pada tabel di bawah ini.

Tabel 1

Substansi Perda Bali Nomor 11 Tahun 2017 tentang Bendega

\begin{tabular}{|c|c|c|c|}
\hline No & Pasal & Substansi & Keterangan \\
\hline 1 & $\begin{array}{l}\text { Pasal } 1 \text { angka } 1 \\
\text { s/d angka } 14\end{array}$ & Ketentuan umum & $\begin{array}{l}\text { Mengatur tentang ketentuan umum yang terkait dengan } \\
\text { pengaturan Bendega. Terdapat unsur negara yang diwakili } \\
\text { oleh peran Pemerintah Daerah dan Gubernur. Kemudian } \\
\text { nilai-nilai ajaran agama Hindu yang tertuang dalam konsep } \\
\text { tri hita karana serta unsur kebiasaan masyarakat yang } \\
\text { tertuang dalam pengaturan krama bendega, prajuru, dan } \\
\text { awig-awig bendega. }\end{array}$ \\
\hline 2 & Pasal 2 & $\begin{array}{l}\text { Ruang lingkup pengaturan } \\
\text { Bendega }\end{array}$ & $\begin{array}{l}\text { Ada beberapa hal yang di atur dalam Perda Bendega } \\
\text { yakni perrlindungan dan pelestarian bendega, tugas dan } \\
\text { kewajiban bendega, kewajiban Pemerintah Daerah, } \\
\text { parhyangan, pawongan dan palemahan, pemberdayaan } \\
\text { bendega, pembinaan dan pengawasan; dan pendanaan }\end{array}$ \\
\hline 3 & $\begin{array}{l}\text { Pasal } 3 \text { s/d pasal } \\
10\end{array}$ & $\begin{array}{l}\text { Mengatur mengenai } \\
\text { perlindungan dan pelestarian } \\
\text { bendega }\end{array}$ & $\begin{array}{l}\text { Pemerintah Daerah berkewajiban melakukan perlindungan } \\
\text { dan pelestarian Bendega sesuai dengan falsafah tri hita } \\
\text { karana yang diatur lebih lanjut dengan Peraturan Daerah } \\
\text { Kabupaten/Kota. Kedudukan bendega sebagai organisasi } \\
\text { tradisional melaksanakan dan melestarikan kearifan lokal } \\
\text { dalam pembangunan ekonomi, sosial, budaya dan relegius } \\
\text { dibidang kelautan dan perikanan yang tunduk pada awig- } \\
\text { awig organisasi bendega yang dipimpin oleh prajuru } \\
\text { bendega. }\end{array}$ \\
\hline 4 & $\begin{array}{l}\text { Pasal } 11 \text { dan } \\
\text { pasal } 12\end{array}$ & $\begin{array}{l}\text { Tugas dan } \quad \text { Kewajiban } \\
\text { bendega }\end{array}$ & $\begin{array}{l}\text { Tugas bendega menjaga dan melestarikan palemahan, } \\
\text { pawongan dan parhyangan; meningkatkan kemampuan } \\
\text { dan pemberdayaan krama bendega dalam } \\
\text { mengembangkan kemitraan usaha; memperjuangkan } \\
\text { kepentingan krama bendega dalam mengembangkan } \\
\text { kemitraan usaha; dan menampung dan menyalurkan } \\
\text { aspirasi krama bendega. Bendega berkewajiban } \\
\text { melaksanakan kewajibannya berlandaskan tri hita karana }\end{array}$ \\
\hline 5 & $\begin{array}{l}\text { Pasal } 13,14 \text { dan } \\
15\end{array}$ & $\begin{array}{l}\text { Perlindungan dan pelestarian } \\
\text { di bidang parahyangan, } \\
\text { pawongan dan palemahan }\end{array}$ & $\begin{array}{l}\text { Perlindungan dan pemberdayaan dibidang Parhyangan } \\
\text { khususnya pura yang berada di wilayah pesisir. } \\
\text { Perlindungan dan pemberdayaan dibidang pawongan, } \\
\text { khususnya krama bendega. Perlindungan dan } \\
\text { pemberdayaan dibidang palemahan, yakni sekitar wilayah } \\
\text { pesisir. }\end{array}$ \\
\hline 6 & Pasal 16 & Pemberdayaan bendega & $\begin{array}{l}\text { Pemerintah daerah dalam hal ini Gubernur melakukan } \\
\text { pemberdayaan kepada bendega dengan cara : membuka } \\
\text { akses kegiatan perekonomian yang berlandaskan kearifan } \\
\text { lokal; penguatan kelembagaan Bendega; dan memberikan } \\
\text { bantuan fasilitas pembiayaan dan permodalan }\end{array}$ \\
\hline 7 & Pasal 17 & Pembinaan dan pengawasan & $\begin{array}{l}\text { Pemerintah Daerah melakukan pembinaan dan } \\
\text { pengawasan terhadap bendega }\end{array}$ \\
\hline
\end{tabular}




\begin{tabular}{|c|l|l|l|}
\hline 8 & Pasal 18 & Pendanaan & $\begin{array}{l}\text { Pendanaan untuk kegiatan Perlindungan dan } \\
\text { Pemberdayaan bendega bersumber dari: anggaran } \\
\text { pendapatan dan belanja daerah; dan/atau sumber } \\
\text { pendanaan lainnya yang sah sesuai dengan ketentuan } \\
\text { peraturan perundang-undangan. }\end{array}$ \\
\hline 9 & Pasal 19 & Ketentuan penutup & $\begin{array}{l}\text { Peraturan Daerah ini mulai berlaku pada tanggal } \\
\text { ditetapkan, yakni pada tanggal 9 Oktober 2017. }\end{array}$ \\
\hline
\end{tabular}

Menarik untuk dilihat ketentuan pasal 4 Peraturan Daerah Provinsi Bali Nomor 11 Tahun 2017 tentang Bendega yang menyatakan Perlindungan dan Pelestarian Bendega diatur lebih lanjut dengan Peraturan Daerah Kabupaten/Kota. Setidaknya sampai saat ini terdapat 2 (dua) Kabupaten dan Kota di Bali yang telah memiliki Peraturan Daerah yang mengatur tentang bendega. Yakni, Kota Denpasar dan Kabupaten Badung yang secara nyata nelayan masih dapat menjaga eksistensinya di pesisir pantai daerah tersebut.

Pertama, Peraturan Daerah Kota Denpasar Nomor 6 Tahun 2019 tentang Perlindungan dan Pelestarian Bendega yang ditetapkan pada tanggal 22 Juli 2019. Sebagai dasar pertimbangan yakni untuk melaksanakan ketentuan pasal 4 Peraturan Daerah Provinsi Bali Nomor 11 Tahun 2017 tentang Bendega, perlu membentuk Peraturan Daerah tentang Perlindungan dan Pelestarian Bendega. Peraturan Daerah ini terdiri dari 7 (tujuh) Bab dan 20 (dua puluh) Pasal. Peraturan ini di masukkan dalam Lembaran Daerah Kota Denpasar Tahun 2019 Nomor 6. Noreg Peraturan Daerah Kota Denpasar, Provinsi Bali: (6 28/2019) dan Tambahan Lembaran Daerah Kota Denpasar Nomor 6.

Kedua, Peraturan Daerah Kabupaten Badung Nomor 6 Tahun 2019 tentang Perlindungan dan Pelestarian Bendega yang ditetapkan pada tanggal 18 Oktober 2019. Sebagai dasar pertimbangan yakni untuk melaksanakan ketentuan pasal 4 Peraturan Daerah Provinsi Bali Nomor 11 Tahun 2017 tentang Bendega, perlu membentuk Peraturan Daerah tentang Perlindungan dan Pelestarian Bendega. Peraturan daerah ini terdiri dari 6 (enam) Bab dan 10 (sepuluh) pasal. Peraturan ini telah dimasukkan dalam Lembaran Daerah Kabupaten Badung Tahun 2019 Nomor 6 Noreg Peraturan Daerah Kabupaten Badung, Provinsi Bali: 6 6, 59
/ 2019 dan Tambahan Lembaran Daerah Kota Denpasar Nomor 6.

\subsection{Model Pluralisme Hukum Pengaturan Bendega di Bali}

Pada Peraturan Daerah Provinsi Bali Nomor 11 Tahun 2017 tentang Bendega terdiri dari IX Bab dan 19 Pasal ditetapkan pada tanggal 9 Oktober 2017 jika dianalisa ternyata mengandung nilai-nilai pluralisme hukum. Teori pluralisme hukum, yang mengedepankan hubungan sinergi antara hukum negara, kebiasaan masyarakat, dan nilai-nilai keagamaan, artinya terintegrasinya kearifan lokal, hukum agama, dan hukum negara dalam satu ramuan hukum pengaturan bendega di Bali dalam teori hukum disebut sebagai pluralisme hukum.

Pluralisme hukum akan mengurangi ketegangan antara universalisme dan lokalisme sehingga stabilitas sosial akan tetap terjaga (James D. Fry, 2014: 1). Pluralisme adalah konsep hukum yang isinya lebih dari satu prinsip dan substansi hukum serta melihat situasi dengan perbedaan keadaan fakta sosial yang ada (Twinning, 2016: 488-489). Tamanaha (2007) menyatakan bahwa pluralisme hukum tersebut ada di mana-mana, baik di tataran hukum lokal, hukum nasional, hukum transnasional, maupun hukum internasional. Artinya, baik hukum tingkat lokal maupun nasional. Kajian pluralisme hukum menentang pernyataan bahwa hukum negara memiliki otoritas yang paling tinggi dibandingkan dengan yang lainnya. Pluralisme hukum muncul sebagai tantangan terhadap konsep-konsep hukum yang berpusat pada negara. Ia mengkritik gagasan bahwa hukum negara merupakan satu-satunya bentuk hukum yang digunakan untuk mengatur masyarakat (Perez, 2011: 1-2). Bahkan, pluralisme hukum dapat menjadi penengah terjadinya konflik nomatif (Berma, 2007: 1155). Pluralisme hukum 
dapat melihat perubahan hukum yang terjadi dalam masyarakat karena adanya sistem hukum berbeda yang mengatur masyarakat tersebut (Taubner, 1996: 3-28). Hukum dalam kajian pluralisme hukum lebih mengedepankan perhatian terhadap kontekstual dalam hukum itu Pluralisme hukum merupakan pembauran normatif yang terjadi akibat berbagai hukum yang saling berinteraksi (Zumbansen, 2010: 141-189).

Teori pluralisme hukum pada dasarnya menekankan pentingnya mengakui bahwa sistem hukum nonnegara, seperti sistem adat atau agama dapat bekerja sama dengan sistem negara. Hal itu telah digunakan terutama oleh para ahli untuk menghasilkan deskriptif dan pekerjaan nonkomparatif (Miranda, 2007). Hukum di masyarakat pasti beragam sehingga perlu ada titik temu (Solum, 2006: 7-23). Pluralisme hukum adalah fitur yang menonjol dalam banyak konteks pembangunan dengan implikasi negatif dan positif untuk supremasi hukum (Tamanaha, 2011: 1). Pluralisme hukum merupakan fakta yang tidak dapat dihindarkan Menski, 2010). Pendekatan pluralisme hukum tidak bertentangan dengan konstitusional (Sweet, 2010: 621). Pluralisme hukum merupakan langkah menuju penghormatan terhadap pengakuan hak asasi manusia secara kolektif (Anaya, 2007: 3). Pada pendekatan pluralisme hukum hubungan antara sistem hukum yang berbeda seharusnya menuju penguatan sistem hukum masing-masing.

Nilai pluralisme hukum yang terkandung dalam Peraturan Daerah Provinsi Bali Nomor 11 Tahun 2017 tentang Bendega sebagai contohnya dapat dilihat pada ketentuan pasal 1 angka 1 sampai angka 14 dimana secara khusus mengatur beberapa unsur antara lain, terdapat unsur negara yang diwakili oleh peran Pemerintah Daerah dan Gubernur. Kemudian nilai-nilai ajaran agama Hindu yang tertuang dalam konsep tri hita karana serta unsur kebiasaan masyarakat yang tertuang dalam pengaturan krama bendega, prajuru, dan awigawig bendega.

Hal tersebut sesuai dengan teori triangular pluralisme hukum menski, (2015) yang menyatakan bahwa suatu hukum termasuk pluralism hukum jika terdapat beberapa unsur yang menggambarkan sebuah segitiga. Pertama, sudut bagian atas mengandung unsur nilai etika, moral dan ajaran agama (dalam hal ini dalam Perda Bendega di wakili unsur ajaran tri hita karana dan ajaran agama Hindu sebagai landasan perlindungan dan pelestarian bendega di Bali). Kedua, sudut segitiga bagian kiri mengandung unsur hukum negara (dalam hal ini dalam Perda Bendega di wakili unsur Pemerintah Daerah dan Gubernur sebagai bagian struktur hukum negara, sedangkan substansi hukum diwakili oleh Peraturan Daerah Provinsi Bali tentang Bendega dan dilanjutkan pengaturannya dalam Peraturan Daerah Kabupaten/ Kota yang mengatur tentang Perlindungan dan Pelestarian Bendega). Ketiga, sudut segitiga bagian kanan mengandung unsur hukum adat atau unsur masyarakat adat (dalam hal ini dalam Perda Bendega di wakili unsur krama bendega, prajuru bendega, dan awig-awig organisasi bendesa).

Jika dikaitkan dengan pluralisme hukum negara (state legal pluralism) seperti disebut Gordon Woodman $(2005 ; 152)$ atau pluralisme hukum yang lemah (weak legal pluralism) seperti disebut John Griffiths (2005: 74-75). Pluralisme hukum negara (state legal pluralism) muncul manakala sebagian hukum negara berasal dari batang tubuh norma yang sejak awalnya memang dibentuk sebagai hukum negara dan sebagiannya lagi berasal dari normanorma non-negara yang diakui hukum negara, seperti hukum adat dan agama. Maka, Peraturan Daerah Provinsi Bali Nomor 11 Tahun 2017 tentang Bendega justru menganut pluralism hukum yang kuat, karena keberadaan hukum adat (awig-awig bendega) diberikan ruang untuk mengatur bendega secara hukum adat masing-masing selain hukum negara yang dibuat oleh pemerintah sehingga memunculkan kemajemukan hukum. Pluralisme merupakan ciri masyarakat majemuk karena di Indonesia terdapat perbedaan-perbedaan suku bangsa, agama, adat, dan kedaerahan sering kali disebut sebagai ciri masyarakat yang bersifat majemuk (Nasikun, 1985: 30). Kebhinekaan agama, suku bangsa dan geografis di Indonesia, suatu kemajemukan yang tidak dapat dihindarkan. Hal itu memerlukan norma politik yang cukup netral untuk menjaga keutuhan dan kedamaian 
negara. Norma politik itu merupakan paham negara hukum Indonesia (Daniel S. Lev, 1990: 188) negara hukum yang mensejahterakan.

\section{PENUTUP}

\subsection{Simpulan}

Adapun simpulan berdasarkan uraian pembahasan di atas, antara lain:

1. Bahwa pengaturan tentang perlindungan dan pelestarian bendega sebagai organisasi tradisional nelayan telah di atur dalam Peraturan Daerah Provinsi Bali Nomor 11 Tahun 2017 tentang Bendega. Kemudian berdasarkan ketentuan pasal 4 peraturan tersebut telah dijabarkan dalam Peraturan Daerah Kabupaten Denpasar Nomor 6 Tahun 2019 tentang Perlindungan dan Pelestarian Bendega dan Peraturan Daerah Kabupaten Badung Nomor 6 Tahun 2019 tentang Perlindungan dan Pelestarian Bendega sebagai aturan tindak lanjutnya.

2. Bahwa Peraturan Daerah Provinsi Bali Nomor 11 Tahun 2017 tentang Bendega mengandung prinsip pluralisme hukum. terdapat beberapa unsur yang menggambarkan sebuah segitiga. Pertama, sudut bagian atas mengandung unsur nilai etika, moral dan ajaran agama (dalam hal ini dalam Perda Bendega di wakili unsur ajaran tri hita karana dan ajaran agama Hindu sebagai landasan perlindungan dan pelestarian bendega di
Bali). Kedua, sudut segitiga bagian kiri mengandung unsur hukum negara (dalam hal ini dalam Perda Bendega di wakili unsur Pemerintah Daerah dan Gubernur sebagai bagian struktur hukum negara, sedangkan substansi hukum diwakili oleh Peraturan Daerah Provinsi Bali tentang Bendega dan dilanjutkan pengaturannya dalam Peraturan Daerah Kabupaten/ Kota yang mengatur tentang Perlindungan dan Pelestarian Bendega). Ketiga, sudut segitiga bagian kanan mengandung unsur hukum adat atau unsur masyarakat adat (dalam hal ini dalam Perda Bendega di wakili unsur krama bendega, prajuru bendega, dan awig-awig organisasibendesa). Tergolong dalam pluralisme hukum kuat.

\subsection{Saran}

Adapun saran yang dapat disampaikan, antara lain:

1. Agar dalam implementasi Peraturan Daerah Provinsi Bali Nomor 11 Tahun 2017 tentang Bendega tetap memperhatikan prinsip-prinsip pluralisme hukum yang melibatkan unsur negara, unsur agama dan unsur adat.

2. Agar aturan pelaksanaan Peraturan Daerah Provinsi Bali Nomor 11 Tahun 2017 tentang Bendega dalam bentuk peraturan Gubernur harus segera dibentuk untuk memberikan efektifitas dalam penerapan perda tersebut. 


\section{DAFTAR PUSTAKA}

Anaya, S. James, Indigenous Law and its Contribution to Global Pluralism (October 7, 2009). Indigenous Law Journal, Vol. 6, p. 3, 2007; Arizona Legal Studies Discussion Paper No 09-33. Available at SSRN: https://ssrn.com/abstract=1485137

B. Solum, Lawrence, Pluralism and Public Legal Reason. William \& Mary Bill of Rights Journal, Vol. 15, pp. 7-23, 2006. Available at SSRN: https://ssrn.com/abstract=960784

Berman, Paul Schiff, the New Legal Pluralism (November 14, 2009). Annual Review of Law and Social Science, Vol. 5, Pp. 225-242, 2009. Available At SSRN: Https://Ssrn.Com/ Abstract $=1505926$

D.fry, James, Pluralism, Religion, and Moral Fairness of International Law, Vo. 3 Oktober 2014, Oxford Journal: Law and Religion, hlm.1, http//m.ojlr.oxfordjournals.org/content/by/year, diakses 13 April 2016.

Forsyth, Miranda, How to 'Do' Legal Pluralism (June 2007). Available at SSRN: https://ssrn.com/ abstract=993617 or http://dx.doi.org/10.2139/ssrn.993617

Griffiths, John, "Memahami Pluralisme Hukum, Sebuah Deskripsi Konseptual, dalam Tim HuMa, eds., Pluralisme Hukum: Sebuah Pendekatan Interdisiplin, (Jakarta: Penerbit Perkumpulan untuk Pembaharuan Hukum Berbasis Masyarakat dan Ekologis (HuMa), 2005).

Hartono, Sunaryati, Politik Hukum Menuju Satu Sistem Hukum Nasional, (Bandung: Alumni, 1991).

Lev, Daniel S., Hukum dan Politik di Indonesia: Kesinambungan dan Perubahan, (Jakarta: LP3ES, 1990).

Mahfud MD, Membangun Politik Menegakkan Konstitusi, (Jakarta: Rajawali Pers, Jakarta, 2010).

Menski, Werner, Flying Kites In A Global Sky: New Models Of Jurisprudence, http://www. sociolegalreview.com/wp-content/uploads/2015/12/flying-Kites-In-A-Global-SkyNew-Models-of-Jurisprudence-Werner-Mensky.pdf, 2015), hlm. 13--14

Menski, Werner, Sanskrit Law: Excavating Vedic Legal Pluralism (2010). SOAS School of Law Research Paper No. 05-2010.

Michaels, Ralf, the Re-State-Ment of Non-State Law: The State, Choice of Law, and the Challenge from Global Legal Pluralism. Wayne Law Review, Forthcoming; Duke Law School Legal Studies Paper No. 81. Available at SSRN: https://ssrn.com/abstract=809244

Nasikun, Sistem Sosial Indonesia, (Jakarta: Rajawali Press, 1985).

Perez, Oren, Legal Pluralism (October 10, 2011). The Oxford Encyclopedia of American Political and Legal History, Donald T. Critchlow and Philip R. Vandermeer, Eds., 2012. Available At Ssrn: Https://Ssrn.Com/Abstract=1929395,

Raharjo, Satjipto, Ilmu Hukum, (Bandung: Citra Aditya Bakti, 2000).

Soedarto, Hukum Pidana dan Perkembangan Masyarakat dalam Kajian Hukum Pidana, (Bandung: Sinar Baru, 1983).

Suseno, Frans Magnis, Etika Politik:Prinsip-Prinsip Dasar Kenegaraan Modern, (Jakarta: Gramedia Pustaka Utama, 1994).

Sweet, Alec Stone, Constitutionalism, Legal Pluralism, and International Regimes (March, 12 2010). Indiana Journal of Global Legal Studies, Vol. 16, pp. 621--45, 2009. Available at SSRN: https://ssrn.com/abstract=1569346

Tamanaha, Brian Z., the Rule of Law and Legal Pluralism in Development (July 1, 2011). Washington University in St. Louis Legal Studies Research Paper No. 11-07-01; Legal Pluralism And Development: Scholars And Practitioners In Dialogue, Caroline Sage, Michael Woolcock, Brian Z. Tamanaha, eds., Cambridge University Press, 2012; Hague Journal on the Rule of Law, Vol. 3, p. 1, 2011; Washington University in St. Louis Legal Studies Research Paper No. 11-07-01. Available at SSRN: https://ssrn.com/abstract=1886572 
Tamanaha, Brian Z., Understanding Legal Pluralism: Past to Present, Local to Global. Sydney Law Review, Vol. 29, 2007; St. John's Legal Studies Research Paper No. 07-0080. Available at SSRN: https://ssrn.com/abstract=1010105

Teubner, Gunther and Peter Korth, Two Kinds of Legal Pluralism: Collision of Transnational Regimes in the Double Fragmentation of World Society (June 8, 2009). Regime Interaction in International Law: Facing Fragmentation, Margaret Young, Ed., Oxford University Press, 2010. Available At SSRN: Https://Ssrn.Com/Abstract=1416041

Twinning, William, Normative and Legal Pluralism: A Global Perspective, Duke Journal of Comparative and International Law, Vol.20:473, (Duke Law University: 2010), Duke Law University,http;//scholarshiplaw.duke.edu, diakses 13 April 2016.

Wahyono, Padmo, Indonesia Negara Berdasatkan atas hukum, Cet. II, (Jakarta: Ghalia Indonesia, 1986).

Wahyono, Padmo, Menyelisik Proses Terbentuknya Perundang-undangan, (Forum Keadilan, No. 29 April 1991).

Woodman, Gordon R., 'Mungkinkah Membuat Peta Hukum?', dalam Tim HuMa, eds., Pluralisme Hukum: Sebuah Pendekatan Interdisiplin, (Jakarta: Penerbit Perkumpulan untuk Pembaharuan Hukum Berbasis Masyarakat dan Ekologis (HuMa), 2005).

Zevenbergen, William dalam Abdul Latif dan Hasbi Ali, Politik Hukum, (Jakarta: Sinar Grafika, Jakarta, 2011).

Zumbansen, Peer C., Transnational Legal Pluralism (January 26, 2010). Transnational Legal Theory, Vol. 10, No. 2, Pp. 141-189, 2010; CLPE Research Paper No. 01/2010. Available At SSRN: Https://Ssrn.Com/Abstract=1542907 